\title{
Study on the slagging of biomass briquette combustion
}

\author{
Ren Xiaoping ${ }^{1}$, Liu Fang ${ }^{2}$, Tang Xintong ${ }^{1}$, Sun Xiaoting ${ }^{1}$, Yang jing ${ }^{1}$, Yang song ${ }^{1}$ \\ ${ }^{1}$ Changchun Institute of Technology \\ ${ }^{2}$ Jiutai power plant of Huaneng Jilin Power Generation Co., Ltd, China
}

\begin{abstract}
China's coal-fired industrial boilers are characterized by high energy consumption, serious pollution, and large output of biomass briquette, which is a clean and high-quality alternative fuel to coal. However, there are serious slagging problems in combustion. Taking straw briquette as an example, this paper introduces its combustion characteristics, studies its slagging mechanism, slagging influencing factors, etc., reveals the slagging problems in essence, and provides theoretical basis for the prevention and control of slagging.
\end{abstract}

\section{Preface}

At present, the total number of coal-fired industrial boilers in use in China is about 500000, and the annual coal consumption is about $1 / 3$ of the total coal production in China, while the annual smoke emission of industrial boilers is about 6-8 million tons, accounting for $33 \%$ of the total smoke emission in China; the $\mathrm{SO}_{2}$ emission is about 500-600 tons, accounting for $21 \%$ of the total emission in China, the $\mathrm{CO}_{2}$ emission is about 600 million tons, and a large amount of NOx is also emitted ${ }^{[1]}$. These industrial boilers use coal as fuel, which not only consume huge energy, but also cause serious environmental pollution.

Biomass resources have the advantages of renewable and clean resources. China is a large agricultural country. Crop straws are the main body of biomass resources, with an annual output of 900 million tons, but $1 / 2$ of them can be used for energy development, equivalent to the 180 million tons of standard coal ${ }^{[2]}$. If fully developed, they can be used to solve the energy and environmental problems. It is of great significance to realize the diversified development and application of biomass resources.

\section{Straw and straw briquette}

Biomass energy is essentially the energy that plants store the solar energy into the organism through the photosynthesis. Crop straw is one of the important sources of biomass energy in China, but the structure of original straw is loose and the energy density is very low, which increases the difficulty of transportation, storage and boiler combustion. Using the method of mechanical pressurization, the original loose straw is compressed into a shaped fuel, which becomes a high-quality and clean energy source with many advantages: First of all, clean combustion can be realized. The ash content of straw is generally less than $3 \%$, and the content of $\mathrm{N}$ and $\mathrm{S}$ is also very low. In addition, although straw combustion will emit $\mathrm{CO}_{2}$, it will absorb $\mathrm{CO}_{2}$ during the growth period, and basically achieve zero $\mathrm{CO}_{2}$ emission. Compared with coal, combustion pollutants are greatly reduced. Secondly, it has good combustion performance. The main combustion component of straw briquette is the volatile, which accounts for $70 \%-80 \%$. It is easy to ignite and burn completely, with high combustion efficiency and no black smoke. In addition, its density is $0.8-1.3 \mathrm{t} / \mathrm{m}^{3}$, the heat value is equivalent to that of medium coal, but the price is lower, which greatly reduces the fuel cost of the boiler.

\section{Combustion characteristics of straw briquette}

In the early stage of the raw straw combustion, a large number of volatile precipitates rapidly and the temperature of precipitation is low. It is found that the $80 \%$ of the volatile can precipitates and burns rapidly at $300^{\circ} \mathrm{C}-350^{\circ} \mathrm{C}^{[2]}$, so that a large number of volatile is produced rapidly and burned, with high combustion intensity, and also prone to lack of oxygen supply. In the middle and late stage of combustion, the main combustion is coke, and the coke content is very low, so combustible components is few, with combustion intensity weak, combustion time short, and prone to oxygen excess; In the burnout stage, the skeleton structure of the remaining coke is very loose and light. It is easy to produce black flocs, flowing with flue gas.

Compared with the original straw, the compact structure of straw briquette makes the release rate of volatile uniform, which avoids the higher concentration of volatile in the early stage of combustion; In the middle stage of combustion, the structure of coke is tight, so that the combustion heat can be orderly released alike coal, In the whole combustion process, the combustion speed is 
relatively uniform, the oxygen supply is stable, the combustion is stable and the combustion efficiency is high. The fire power is longer-lasting in the combustion cycle, and the combustion time is obviously prolonged, and the furnace temperature is obviously increased. In the burnout stage, the skeleton structure of its ash is also relatively compact, and there is no black flocs in the flue gas.

\section{Slagging mechanism of straw briquette}

It is easy to produce slagging phenomenon when straw briquette is burned in the boiler, which endangers the safe and economic operation of the boiler. At the same time, it increases the difficulty for the popularization and utilization of straw briquette. In this regard, domestic scholars ${ }^{[3,4,5]}$ have carried out a lot of researches on the slagging of biomass briquette fuel, and found that there are two reasons for the slagging of straw briquette fuel. On the one hand, the sulfidation reaction of alkali metal causes slagging. Because of the high content of chlorine in straw, alkali metal mainly precipitates in the form of chloride during combustion. After alkali metal precipitates, it will change into the gas-solid phase. The solid phase mainly exists in the form of silicate, while the gas phase mainly consists of alkali metal chloride, alkali metal sulfate and alkali metal hydroxide. Taking $\mathrm{K}$ as an example, $\mathrm{K}$ precipitates from the fuel surface in the form of $\mathrm{KCl} . \mathrm{SO}_{3}$ and $\mathrm{KCl}$ in the flue gas make the gaseous $\mathrm{KHSO}_{4}$ and solid $\mathrm{K}_{2} \mathrm{SO} 4$ through chemical reaction under certain conditions, and the gaseous $\mathrm{KHSO}_{4}$ solidifies after encountering the heating surface with lower temperature. The higher the combustion temperature is, the more alkali metal gaseous products will be. These gaseous products will condense on the heat exchange surface in a molten state and form a viscous surface, which is mainly composed of basic substances such as sodium sulfate, calcium sulfate or sodium, eutectic of calcium and sulfate ${ }^{[4]}$. They usually have low melting point, high viscosity and high strength. Once they adhere to the heating surface, it is very difficult to remove them. On the other hand, the slag is induced by alkali silicate. The main chemical components of straw ash include potassium salt, silicon dioxide, calcite, potassium iron oxide and magnesium oxide. When the temperature of them rises from $850^{\circ} \mathrm{C}$ to $1050^{\circ} \mathrm{C}$, the mineral components of straw ash have changed. The oxides of $\mathrm{Si}$ and silicate in straw ash react with potassium salt to form the alkali metal silicate with lower melting point, which directly accelerating slagging of ash.

\section{Slagging factors}

Straw briquette is rich in alkali metals such as potassium, sodium and chlorine, which is the internal cause of serious slagging, but the external conditions such as combustion temperature, combustion time and combustion conditions have a great impact on the slagging characteristics of straw fuel.

\subsection{The Relationship between slagging and ash composition}

The chemical composition of straw briquette fuel ash generally includes $\mathrm{SiO}_{2}, \mathrm{Fe}_{2} \mathrm{O}_{3}, \mathrm{Al}_{2} \mathrm{O}_{3}, \mathrm{TiO}_{2}, \mathrm{CaO}, \mathrm{MgO}$, $\mathrm{Na}_{2} \mathrm{O}, \mathrm{K}_{2} \mathrm{O}$, etc., which contains a large number of alkali metal oxides, but the melting point of alkali metal oxides is low, especially $\mathrm{K}$ and $\mathrm{Na}$ oxides, most of which have a melting point of $800-1000^{\circ} \mathrm{C}$. Domestic scholars ${ }^{\mathbf{I}_{6} \mathbf{I}}$ have tested the ash composition and ash melting point respectively formed by the wheat straw, the rice straw and the corn straw. The test results are shown in Table 1 and Table 2 .

Table 1. Composition of biomass ash

\begin{tabular}{|c|c|c|c|c|}
\hline \multicolumn{2}{|c|}{ Types of biomass ash } & \multirow{2}{*}{$\begin{array}{c}\begin{array}{c}\text { Rice stem } \\
\text { ash }\end{array} \\
74.67\end{array}$} & \multirow{2}{*}{ 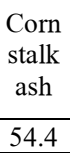 } & \multirow{2}{*}{ 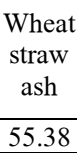 } \\
\hline \multirow{8}{*}{$\begin{array}{c}\text { Ash } \\
\text { composition } \\
(\%)\end{array}$} & $\mathrm{SiO}_{2}$ & & & \\
\hline & $\mathrm{Fe}_{2} \mathrm{O}_{3}$ & 0.85 & 4.35 & 0.73 \\
\hline & $\mathrm{Al}_{2} \mathrm{O}_{3}$ & 1.04 & 7.81 & 1.88 \\
\hline & $\mathrm{TiO}_{2}$ & 0.09 & 0.44 & 0.08 \\
\hline & $\mathrm{CaO}$ & 3.01 & 4.83 & 6.14 \\
\hline & $\mathrm{MgO}$ & 1.75 & 2.41 & 0.16 \\
\hline & $\mathrm{Na}_{2} \mathrm{O}$ & 0.96 & 1.87 & 1.71 \\
\hline & $\mathrm{K}_{2} \mathrm{O}$ & 12.3 & 6.61 & 13.60 \\
\hline
\end{tabular}

Table 2. ash melting characteristics

\begin{tabular}{|c|c|c|c|}
\hline Types of biomass ash & $\begin{array}{c}\text { Rice } \\
\text { stem } \\
\text { ash }\end{array}$ & $\begin{array}{c}\text { Corn } \\
\text { stalk } \\
\text { ash }\end{array}$ & $\begin{array}{c}\text { Wheat } \\
\text { straw } \\
\text { ash }\end{array}$ \\
\hline Deformation temperature $\left({ }^{\circ} \mathrm{C}\right)$ & 1050 & 1160 & 1040 \\
\hline Softening temperature $\left({ }^{\circ} \mathrm{C}\right)$ & 1196 & 1198 & 1163 \\
\hline Flow temperature $\left({ }^{\circ} \mathrm{C}\right)$ & 1250 & 1238 & 1190 \\
\hline
\end{tabular}

From the test results of Table 1, the content of $\mathrm{SiO}_{2}$ in the ash is the highest, but the content of $\mathrm{K}_{2} \mathrm{O}$ and $\mathrm{Na}_{2} \mathrm{O}$ is also very high. During the process of ash heating, the alkali metal silicate with low melting point is easy to form. In addition, although the melting point of $\mathrm{CaO}$ in the ash is high, it is easy to form complex eutectic with low melting point, which aggravates the decrease of ash melting point ${ }^{[2]}$.

From table 2, it can be found that value of (ST-DT)of rice straw ash is $146^{\circ} \mathrm{C}$, that of corn straw ash is $38^{\circ} \mathrm{C}$, that of wheat straw ash is $123^{\circ} \mathrm{C}$, and the temperature difference between the softening temperature and the deformation temperature of three kinds of biomass ash is totally less than $150^{\circ} \mathrm{C}$, which makes the coexistence time of solid slag and liquid slag very short. When the temperature exceeds the deformation temperature, the ash is easy to soften, or even melted, resulting in slagging.

\subsection{The relationship between slagging and combustion temperature.}

Qin Jianguang ${ }^{[7]}$, Yan Weiping ${ }^{[8]}$ found that the straw briquette ash can show the signs of melting above $700^{\circ} \mathrm{C}$ and the signs of the complete melting above $900^{\circ} \mathrm{C}$ under 
experimental conditions. In order to reduce the slagging of straw, the flue gas temperature at the furnace outlet is controlled below $850^{\circ} \mathrm{C}$.

\subsection{Relationship between slagging and combustion time}

With the different combustion time, the composition of ash is obviously different, which results in different ash melting point. Zhang $\mathrm{Yi}^{[3]}$ found that when the straw was heated for $60 \mathrm{~min}, 90 \mathrm{~min}$ and $120 \mathrm{~min}$ respectively at $850^{\circ} \mathrm{C}$, the initial ash composition was mainly silicate formed by $\mathrm{K}, \mathrm{Ca}$ and $\mathrm{Al}$; And then it is gradually transformed into the compounds formed by $\mathrm{Mg}, \mathrm{Fe}$ and $\mathrm{Al}$, such as $\mathrm{Mg}(\mathrm{OH})_{2}, \mathrm{Fe}_{2} \mathrm{SiO}_{4}$, besides the silicate formed by $\mathrm{K}, \mathrm{Ca}$ and $\mathrm{Al}$. In the final, the ash formed is still complex in composition, and the content of $\mathrm{Ca}$ salt in the ash is more than that formed in $60 \mathrm{~min}$. In addition, there are the potash feldspar and the complex compounds formed by potassium, magnesium and iron, which results in the low-temperature eutectic, thus reducing the ash melting point.

\subsection{Relationship between slagging and combustion conditions}

The thickness of fuel layer and excess air coefficient have great influence on slagging, Wang huaidong ${ }^{[9,10,11]}$ found that the thicker the fuel layer, the higher the fuel center temperature, and the easier to reach ash melting point in the stoker furnace. In addition, the thicker the fuel layer, the easier to appear reductive atmosphere, which further aggravates the slagging of ash. The slagging increases with the increase of excess air coefficient. When it is less than 1.86 , the slagging is lighter.

\section{Summary}

The straw briquette has the advantages of high calorific value as coal, and the high volatile content and low pollution as straw. It is a kind of clean and renewable high-quality energy and the ideal substitute for coal.

The straw briquette fuel is prone to serious slagging in the process of combustion and utilization. From the slagging formation mechanism, straw itself is rich in $\mathrm{K}$, $\mathrm{Na}$ and other alkali metals and $\mathrm{Cl}$ elements, which is the fundamental internal cause of slagging. They cause slaging mainly by the formation of alkali silicate and the sulfuration reaction of alkali metals in the combustion process.

In the combustion and utilization of straw briquette fuel, external factors, such as combustion temperature, combustion time and combustion conditions, also have a very important impact on the slagging. Due to the short temperature interval between the softening temperature and the deformation temperature of the ash, and the low deformation temperature, the combustion temperature should be controlled below $850^{\circ} \mathrm{C}$. The longer the combustion time is, the larger the quantity of low melting point eutectic production is, and the combustion time should not exceed 60min. In the layer combustion furnace, the thicker the fuel layer is, the more serious the slagging is, and the fuel layer should be controlled within $60 \mathrm{~mm}$ thick. The larger the excess air coefficient is, the more serious the slagging is. Controlling the excess air coefficient is no more than 2 , which is beneficial to reducing slagging.

NOTES: This topic comes from This topic comes from the Changchun Institute of Technology

Project No: 320190019

Project name: Study on the slagging characteristics and control technology of corn straw briquette burning furnace

\section{References}

1. Liu yaqin, Analysis on the development of biomass combustion technology in industrial boilers, Industrial boiler, 2-3, (2009)

2. Ma xiaoqin, etc. Prospect analysis of transforming small coal-fired boiler into straw shaped fuel boiler, Rural energy, 20-22, (2010)

3. Zhang yi, Study on the mechanism and control technology of biomass briquette slagging, North China University of Technology, (2017)

4. Li Wenya, Study on slagging mechanism of biomass briquette boiler based on electron microscope, Henan Science, 32, 1972-1975, (2014)

5. Shi zaitao. Experiment and analysis of slagging characteristics of wheat straw. Zhejiang agricultural science, 6, 1406-1408, (2011)

6. Xia xuning, Experimental study on slagging characteristics of biomass briquette fuel chain boiler, Henan agricultural university, (2016)

7. Qin Jianguang, Research and development of straw combustion technology in fluidized bed, Water conservancy and electric machinery, 28, 71-75, (2006)

8. Yan Weiping. Analysis and discrimination of slagging characteristics of biomass fuel. Journal of North China Electric Power University, 34, 49-54, (2007)

9. Wang huaidong, etc. Experimental study on slagging characteristics and influencing factors of biomass briquette in the stoves. Journal of Hebei Agricultural University, 42, 206-209, (2008)

10. Liu shengyong, etc. Experimental study on slagging characteristics of biomass briquette combustion equipmen. Journal of Agricultural Engineering, 22, 136-137, (2006)

11. Wu wenge. Coking and ash analysis of biomass boiler and Countermeasures. China chemical equipment. 1, 41-44, (2015) 